\title{
SOMATIC, AUDITORY, VISUAL, INTELLECTUAL (SAVI): ITS EFFECTIVENESS TO TEACH WRITING FROM THE PERSPECTIVE OF STUDENTS' CRITICAL THINKING
}

\author{
Linda Septiyana, Dewi Rochsantiningsih, Ngadiso \\ Sebelas Maret University, Surakarta \\ Email: lindaseptiyanals@gmail.com
}

\begin{abstract}
SAVI is a method used in teaching and learning process which has four main aspects, they are Somatic, it is learning by moving and doing; Auditory, it is learning by talking and hearing; Visual, it is learning by observing and seeing; Intellectual, it is learning by problem solving and reflecting. This article refers to an experimental study on the effectiveness of SAVI to teach writing at one of senior high school in Metro, Lampung. The samples were two classes namely experimental class which was taugh using SAVI and control class which was taught by TSTS. Each class consisted of two groups based on the level of critical thinking (high and low). To gain the data, two instruments were used namely writing test and critical thinking test. The data were, then, analysed by using Multifactor Analysis of Variance ANOVA $2 \mathrm{X} 2$ and Tukey test. Before conducting the ANOVA test, prerequisite test namley normality and homogeneity test were conducted. The findings of this research are: (1) SAVI is more effective than TSTS (2) The students with high critical thinking have better writing skill than those having low critical thinking; and (3) There is an interaction between teaching methods and students' critical thinking in teaching writing. Therefore, it is recommended for English teachers to implement SAVI in teaching writing activities because this method gives positive contribution in improving the students writing skill and facilitating the students' critical thinking to produce a good text.
\end{abstract}

Keywords: Writing, Somatic, Auditory, Visual, Intellectual (SAVI), Two Stay Two Stray, critical thinking, experimental study

\section{INTRODUCTION}

English as one of the languages plays an important role in communication not only its function as a global language but also its use in relevance with the science and technology. As a result, nearly every country in the world feels the necessity to learn English and some of them take a realistic step by placing English as either a foreign or a second language to be taught in schools. Furthermore, the teaching of English in some countries have been started from the beginning level such as kindergarten or elementary school.

English language skills consist of speaking, listening, reading, and writing skill. The four skills are taught to students to prepare them in facing the world challenges. Indonesia is one of the countries which includes 
English in the school curriculum and is tested in the national examination. By having observation on the growth of the world technology and education, Indonesia should prepare the young generation to be skillfull and competent, especially in writing skill.

Writing is an activity of conveying or expressing thoughts and ideas into a paper. Writing can be used for many purposes in life in order to communicate message to others and to provide something for the people themselves, either in informal or formal way. In informal way, written text is usually produced for the sake of the writer himself or herself, like shopping list, diary, and reminder. In formal way, the written text requires more consideration on the use of standard language and certain rules which separate it from oral language. Formal writing is mainly employed in making essays, report, thesis, and etc.

Writing is a fundamental skill, as important as speaking, listening and reading. Harmer (1998) describes four main reasons for teaching writing. First, some students, instead of acquiring a language in oral way, benefit greatly from seeing the language that is written down. Writing reinforces the grammatical structures and vocabulary that students have learned. Second, writing process helps students to think and select words as well as sentences to construct good written text. It is all part of learning experience that can foster the language mastery of the students. Besides, not all people can deliver what they think orally and quickly. By writing students may have more time to think and produce a language in a slower way to reflect what they have learrned. Finally it is essential for students to know how to write a letter, how to make a report, and how to write an essay, etc. They need to know about writing's special conventions such as punctuation, spelling, grammar, mechanic, etc.

In fact, sometimes writing is thought as the most difficult skill to master, particularly in Indonesia, where English is considered as a foreign language. Writing in a foreign language is not an easy task and requires a lot of practice and training because students have to produce a well-accepted written form that is readable and understandable (AlMekhlafi, 2011: 17). Moreover, written form needs more explicit language as it is not delivered directly to the readers. Not only do writer's express idea into a paper, but also should pay attention to the conventions used for writing. Hence, students in writing class are expected to produce written text by demonstrating command of standard written English such as using appropriate structure, accurate grammar, spelling and punctuation, appropriate use of vacabulary and good organization of ideas manifested in coherent paragraphs (Hinkel, 2004:19).

To gain a successful teaching and learning of writing, a teacher should be aware of many factors that can influence the process and the product of students' writing. The factors that can influence the process and the product of students' writing may come from outside or inside the students. The external factors can be in the form of teaching methods used by the teacher, the learning materials and classroom atmosphere. The internal factors deal much with psychological condition of the 
students, such as motivation, critical thinking, interest, self- confidence, self- concept, self- esteem, and selfefficacy. It is important for the teacher to examine the students' needs and characteristics dealing with the individual differences that must exist in every class. It will help the teachers fit the teaching objectives and the learning aids for the students. Of all factors mentioned above, there are two factors that should be taken into account, namely teaching methods used in the class and students' critical thinking. There is no doubt that a method plays an important role for the success of the language teaching and learning. In teaching writing, the effective method is the one that can give a significant contribution toward the improvement of the students' writing skill.

In difining what is meant by writing, some experts have their definitions. According to Linse (2005: 98), writing can be said simply as the act of picking up a pencil and forming letters either by printing or writing them in cursive. With the same tone, Barkley, et al. (2005: 233) assert that writing is a means for learning because on a general basis, writing can teach critical thinking by helping students organize, summarize, integrate, and synthesize diverse elements into a coherent whole. Furthermore, Nunan (2003: 88) defines that writing is a process of thinking to invent ideas, thinking how to express into good writing, and arranging ideas into statement and paragraph clearly. In line with the theories above that writing is an activity of forming and arranging words, sentences, paragraphs, with the use of writing materials and the reference to certain rules and conventions to express and communicate thoughts, ideas, perceptions, and feelings to others.

Some experts also have their own definitions about Somatic, Auditory, Visual, Intellectual (SAVI). Meier (2002) states that Meier (2002) states that SAVI method is one of teaching methods in the new learning way, Accelerated Learning. Accelerated Learning (AL) is one of the most sophisticated learning styles nowdays. A-L is based on sophisticated reserach about combining brain and learning. In this learning style it can use method and media broadly and flexibly. Learning does not automatically improved by having people stand up and move around. But combining physical movement with intellectual activity and the use of all the senses can have a profound effect on learning. There are four elements in SAVI. Somatic, learning by moving or doing; Auditory, learning by talking or hearing; Visual, learning by observing or seeing; Intellectual, learning by problem solving or reflecting. The above four way of learning must exist so that learning can take place optimally. Because its elements are integrated, best learning can happen if they are used simultaneously. Moreover, Rose (2001) mentions that Accelerated Learning is a way of learning that uses the methods that match the students' preffered learning style so that the students can learn naturally, easily, quickly and enjoyably. Furthermore, he explains that the methods used in Accelerated Learning include motivating the students' mind, acquiring the information, searching out the meaning, trigerring the memory, exhibit what the students know, and reflecting on how the students have learnt. From those definitions, it can 
be concluded that SAVI is a method to learn quickly for each individual learning style by combining physical movement with intellectual activity. The elements are somatic (learning by moving and doing), auditory (learning by hearing and talking), visual (learning by observing and picturing), and intellectual (learning by problem solving and reflecting). These four elements must be exist in the learning process and can not be separated one each other because these four elements are complementary.

There are some definitions from some experts about Two Stay Two Stray. According to Lie (2002: 61-62) TSTS is one of the cooperative method that gives a chance to the group to share the result and information to other groups. It is done because a lot of learning activities are individual oriented activities. The students work alone and are not allowed to look at other students' works; though, in fact, in the real life out of the school life, the life and the work of the people depend one to another. In addition, Suprijono (2009: 93) mentions that TSTS method is one of the discussion method that begins from the formation of group, two members of the group become hosts who give material or information and two members become guests to look for information from other groups. In line with those definitions above, it can concluded that TSTS method is one of the cooperative learning models that require students to work in group, in which they share their ideas to others and exchange them with other groups, to obtain the best understanding of learning material. The students will work in group then they will try to share what the group has comprehended to other groups. There are four steps of Two Stay Two
Stray in teaching writing, they are preparation, presentation, practice and performance.

Besides the teaching methods, a teacher should be aware of psychological aspects affecting the students' writing skill in the class. One of them is the students' critical thinking. Critical thinking is the mode of thinking about any subject, content, or problem in which the thinker improves the quality of his/her thinking by skillfully taking charge of the structures inherent in thinking and imposing intellectual standards upon them. Scriven and Paul (2009: 1) define critical thinking as the intellectually disciplined process of actively and skillfully conceptualizing, applying, analyzing, synthesizing, and/ or evaluating information gathered from, or generated by, observation, experience, reflection, reasoning, or communication, as a guide to belief and action. Furthermore, Elder and Paul (2008) say that critical thinking is self-guided, self-disciplined thinking which attempts to reason at the highest level of quality in a fair-minded way. People who think critically consistently attempt to live rationally, reasonably, and emphatically. Then, Moon (2008: 25) says that it is clear that critical thinking is something to do with the processes of learning - but it is not all learning. It would seem to be a process in which we generate knowledge by bringing to bear a particular way of working with knowledge. It can be summarized that critical thinking is the abilty to apply, analyze, evaluate, and synthesize gathered information. It means correct critical thinking in the pursuit of relevant and reliable knowledge about the world. Another way to describe it is reasonable, reflective, responsible, and skillful thinking that is focused on 
deciding what to believe or do. A person who thinks critically can ask appropriate questions, gather relevant information, efficiently and creatively sort through this information, reason logically from this information, and come to reliable and trustworthy conclusions about the world that enable one to live and act successfully in it.

From the previous research dealing SAVI method, the researcher sees that some studies do not investigate the influence of SAVI on the students' writing skill from the perspective of their critical thinking. So, the researcher makes further investigation about the effectiveness of SAVI to teach writing from the perspective of students' critical thinking.

\section{RESEARCH METHOD}

This research was conducted at one of senior high school in Metro, Lampung. This research was conducted from September 2015 to October 2015. The researh method used in this research was experimental research. The researher used quasiexperimental design because the population was taken from two classes that already exist at that school. The design of this research was a simple factorial design $2 \times 2$ with Post- Test Only Design. In the Post-Test Only Design, the subject of the research was chosen to determine the experimental group and control group. The experimental group was taught writing by SAVI while the control group by using TSTS. At the end of the treatments, both experimental and control groups were given post-tests. In this post-test only design, the two groups of the subjects were first assigned to the different treatments or control conditions. Then the experimental group and control group were given a post test in the form of writing test. The result was analyzed by comparing the post-test scores of both groups by using ANOVA or Ftest and then by using Tukey test.

The population of this research was the eleventh grade students at one of senior high school in Metro in the academic year of 2015/2016. There were 260 students, consisting of 9 classes. This research had two classes, one class as the experimental group and one as the control group. Each class consisted of 28 students, so there were 56 students as sample. And the researcher used cluster random sampling.

The researcher used two instruments of collecting data in this study. There were writing test to know the students' writing skill and critical thinking test to know the level of students' critical thinking. These two tests was assessed by using readability of the test instruction which informs whether the test instructions are appropriately readable for students and whether the instruction of writing and critical thinking test can be understood by the students. And the result of the questionnaire showed that more than $80 \%$ of students answered "Yes" for each item in the instruction. It can be concluded that writing and critical thinking test in this research is readable since $80 \%$ students could understand the instruction of the test.

The techniques used in analyzing the data were descriptive analysis and inferential analysis. Descriptive analysis was used to know the mean, median, mode and standard deviation of the scores of the writing test. To know the normality and the homogeneity of the data, the reseacher used normality and homogeneity test. The normality and homogeneity tests 
were done before testing the hypothesis. Inferential analysis used was multifactor analysis of variance $2 \times 2$. It was used to test the hypotheses. $\mathrm{H}_{\mathrm{o}}$ is rejected if $\mathrm{F}_{\mathrm{o}}$ is higher than $\mathrm{F}_{\mathrm{t}}$. If $\mathrm{H}_{\mathrm{o}}$ is rejected, the analysis was continued to know which group is better by using Tukey test.

\section{RESEARCH FINDINGS AND DISCUSSIONS}

To test the hypothesis of this research using Multifactor Analysis of Variance (ANOVA) 2x2. Before ANOVA and Tukey Test, there are two kinds of test. Those are normality test and homogeneity test. The result of the tests is used as the requirement before ANOVA test and Tukey Test.

There are eight groups: : (1) the data of the students who are taught using SAVI $\left(\mathrm{A}_{1}\right)$; $(2)$ the data of the students who are taught using TSTS $\left(\mathrm{A}_{2}\right)$; (3) the data of the students having high critical thinking $\left(\mathrm{B}_{1}\right)$; (4) the data of the students having low critical thinking $\left(\mathrm{B}_{2}\right)$; (5) the data of the students having high critical thinking who are taught using SAVI $\left(\mathrm{A}_{1} \mathrm{~B}_{1}\right)$; (6) the data of the students having low critical thinking who are taught using SAVI $\left(\mathrm{A}_{1} \mathrm{~B}_{2}\right)$; (7) the data of the students having high critical thinking who are taught using TSTS $\left(\mathrm{A}_{2} \mathrm{~B}_{1}\right) ;(8)$ the data of the students having low critical thinking who are taught using TSTS $\left(\mathrm{A}_{2} \mathrm{~B}_{2}\right)$.

The result of normality test for the eight groups are: (1) The writing scores computation result of the students taught using Somatic, Auditory, Visual, Intellectual $\left(\mathrm{A}_{1}\right)$ shows that the highest value of $\mathrm{L}_{o}$ is 0.095 with $\mathrm{L}_{t}$ is 0.161 ; (2) The writing scores computation result of the students taught using using Two Stay Two Stray $\left(\mathrm{A}_{2}\right)$ shows that the highest value of $L_{o}$ is 0.0911 with $L_{t}$ is 0.161 ;
(3) The writing scores computation result of the students having high critical thinking $\left(\mathrm{B}_{1}\right)$ shows that the highest value of $\mathrm{L}_{\mathrm{o}}$ is 0.0879 with $\mathrm{L}_{t}$ is 0.161 ; (4) The writing scores computation result of the students having low critical thinking $\left(\mathrm{B}_{2}\right)$ shows that the highest value of $\mathrm{L}_{\mathrm{o}}$ is $0.1429 \mathrm{~L}_{\mathrm{t}}$ is 0.161 ; (5) The writing scores computation result of the students having high critical thinking taught using Somatic, Auditory, Visual, Intellectual $\left(\mathrm{A}_{1} \mathrm{~B}_{1}\right)$ shows that the highest value of $L_{0}$ is 0.0907 with $\mathrm{L}_{\mathrm{t}}$ is 0.227 ; (6) The writing scores computation result of the students having low critical thinking taught using Somatic, Auditory, Visual, Intellectual $\left(\mathrm{A}_{1} \mathrm{~B}_{2}\right)$ shows that the highest value of $L_{0}$ is 0.1335 with $L_{t}$ is 0.227 ; (7) The writing scores computation result of the students having high critical thinking taught using Two Stay Two Stray $\left(\mathrm{A}_{2} \mathrm{~B}_{1}\right)$ shows that the highest value of $\mathrm{L}_{0}$ is 0.1095 with $\mathrm{L}_{\mathrm{t}}$ is 0.227 ; and (8) The writing scores computation result of the students having low critical thinking taught using Two Stay Two Stray $\left(\mathrm{A}_{2} \mathrm{~B}_{2}\right)$ shows that the highest value of $L_{o}$ is 0.1628 with $L_{t}$ is 0.227 . The data can be said as normal data if $\mathrm{L}_{\mathrm{o}}$ ( $\left.\mathrm{L}_{\text {obtained }}\right)$ is lower than $\mathrm{L}_{\mathrm{t}}\left(\mathrm{L}_{\text {table }}\right)$ at the level of significance $\alpha=0.05$. From the result, it can be concluded that all the data of writing scores for the eight groups are in normal distribution because $L_{0}$ of the entire data are lower than $\mathrm{L}_{\mathrm{t}}\left(\mathrm{L}_{\mathrm{o}}<\mathrm{L}_{\mathrm{t}}\right)$ at the level of significance $\alpha=0.05$.

The result of homogeneity test is 5.06. The data are homogeneous if $\chi_{0}{ }^{2}$ $\left(\chi_{\text {obtained }}\right)$ is lower than $\chi_{t}^{2}\left(\chi_{\text {table }}\right)$ at the level of significance $\alpha=0.05$. Because $\chi_{0}^{2}(5.06)$ is lower than $\chi_{t}^{2}(7.81)$, it can be said that the data are homogeneous. It means that the data 
of this research are obtained from homogeneous sample.

After the data are normal and homogeneous, then the data are analysed by using Multifactor Analysis of Variance (ANOVA) $2 \times 2$. This test is used to know the effects of the independent variables and attributive variable toward the dependent variable. In addition, it functions to check if there is an interaction among those variables. The hypothesis is rejected if Fo is higher than $\mathrm{Ft}(\mathrm{Fo}>\mathrm{Ft})$. The mean scores and summary of the data is presented in table 1 and 2.

Table 1. The Mean Scores

\begin{tabular}{cccc}
\hline & $\begin{array}{c}\text { SAVI } \\
\text { (A1) }\end{array}$ & $\begin{array}{c}\text { TSTS } \\
\text { (A2) }\end{array}$ & \\
\hline $\begin{array}{c}\text { High Critical } \\
\text { Thinking (B1) }\end{array}$ & 79.00 & 65.93 & 72.46 \\
$\begin{array}{c}\text { Low Critical } \\
\text { Thinking (B2) }\end{array}$ & 66.50 & 71.50 & 69.00 \\
\hline Total & 72.75 & 68.71 & 70.73 \\
\hline
\end{tabular}

Table 2. The Summary of ANOVA $2 \mathrm{X} 2$

\begin{tabular}{|c|c|c|c|c|c|}
\hline $\begin{array}{l}\text { Source of } \\
\text { variance }\end{array}$ & SS & df & MS & $\mathrm{F}_{\mathrm{o}}$ & $\mathrm{F}_{\mathrm{t}(0,05)}$ \\
\hline $\begin{array}{l}\text { Between } \\
\text { columns }\end{array}$ & 228,02 & 1 & 228,02 & 6,487 & 4,00 \\
\hline $\begin{array}{l}\text { Between } \\
\text { rows }\end{array}$ & 168,02 & 1 & 168,02 & 4,780 & \\
\hline $\begin{array}{l}\text { Columns by } \\
\text { rows } \\
\text { (interaction) }\end{array}$ & 1143,02 & 1 & 1143,02 & 32,516 & \\
\hline $\begin{array}{l}\text { Between } \\
\text { Group }\end{array}$ & 1539,05 & 3 & 513,018 & & \\
\hline $\begin{array}{l}\text { Within } \\
\text { group }\end{array}$ & 1827,93 & 52 & 35,152 & & \\
\hline Total & 3366,98 & 55 & & & \\
\hline
\end{tabular}

a. Because $\mathrm{F}_{\mathrm{o}}$ between columns (6.487) is higher than $F_{t}$ at the level significance $\alpha=0.05$ (4.00), $\mathrm{H}_{\mathrm{o}}$ is rejected and the difference between columns is significant. Because the mean of $A_{1}$ (72.75) is higher than that of
$\mathrm{A}_{2}$ (68.71), it can be concluded that SAVI is more effective than TSTS to teach writing.

b. Because $F_{0}$ between rows (4.780) is higher than $F_{t}$ at the level significance $\alpha=0.05$ (4.00), $\mathrm{H}_{\mathrm{o}}$ is rejected and the difference between rows is significant. It can be concluded that the writing skill of students who have high and those who have low critical thinking are significantly different. Then, because the mean of $B_{1}(72.46)$ is higher than that of $B_{2}(69)$, it can be concluded that the students having high critical thinking have better writing skill than those having low critical thinking.

c. Because $F_{o}$ columns by rows (32.516) is higher than $F_{t}$ at the level significance $\alpha=0.05$ (4.00), $\mathrm{H}_{\mathrm{o}}$ is rejected and there is an interaction between teaching methods and students' critical thinking to teach writing. Thus, it can be concluded that the effectiveness of teaching methods is influenced by the levels of students' critical thinking. Students having high critical thinking have better writing skill than those having low critical thinking when they are taught using SAVI Method. On the other hand, students having low critical thinking have better writing skill than those having high critical thinking when they are taught using TSTS Method.

And after knowing the effects and the interaction of independent variables toward the dependent variable, it is also necessary to compare the mean of every treatment 
with the other means using Tukey test. This test is used to identify which means are significantly different from the other. The summary of the data is presented in table 3 .

Table 3. The Summary of Tukey Test

\begin{tabular}{ccccccc}
\hline No & Data & Sample & $\mathrm{q}_{\mathrm{o}}$ & $\mathrm{q}_{\mathrm{t}}$ & $\alpha$ & Status \\
\hline 1 & $\mathrm{~A}_{1}$ and & 28 & 3.60 & 2.89 & 0.05 & Significant \\
& $\mathrm{A}_{2}$ \\
2 & $\mathrm{~B}_{1}$ and \\
$\mathrm{B}_{2}$ & 28 & 3.09 & 2.89 & 0.05 & Significant \\
& $\begin{array}{c}\mathrm{A}_{1} \mathrm{~B}_{1} \\
\text { and }\end{array}$ & 14 & 8.25 & 3.03 & 0.05 & Significant \\
& $\begin{array}{c}\mathrm{A}_{2} \mathrm{~B}_{1} \\
\mathrm{~A}_{1} \mathrm{~B}_{2} \\
\text { and }\end{array}$ & & & & & \\
4 & 14 & 3.16 & 3.03 & 0.05 & Significant \\
& $\mathrm{A}_{2} \mathrm{~B}_{2}$ & & & & & \\
\hline
\end{tabular}

From the result of the Tukey computation above, it can be said:

a. Because $\mathrm{q}_{\mathrm{o}}$ between columns $\left(\mathrm{A}_{1}-\mathrm{A}_{2}\right)$ (3.60) is higher than $\mathrm{q}_{\mathrm{t}}$ at the level significance $\alpha=0.05$ (2.89), applying SAVI is significantly different from TSTS to teach writing. Because the mean of $A_{1}$ (72.75) is higher than that of $A_{2}$ (68.71), it can be concluded that SAVI is more effective than TSTS to teach writing.

b. Because $\mathrm{q}_{\mathrm{o}}$ between columns $\left(B_{1}-B_{2}\right)$ (3.09) is higher than $\mathrm{q}_{\mathrm{t}}$ at the level significance $\alpha=0.05$ (2.89), it can be said that the students who have high critical thinking and those who have low critical thinking are significantly different in their writing skill. Because the mean of $\mathrm{B}_{1}$ (72.46) is higher than that of $B_{2}(69)$, it can be concluded that the students having high critical thinking have better writing skill than those having low critical thinking.

c. Because $\mathrm{q}_{\mathrm{o}}$ between cells $\left(\mathrm{A}_{1} \mathrm{~B}_{1^{-}}\right.$ $\left.A_{2} B_{1}\right)(8.25)$ is higher than $q_{t}$ at the level significance $\alpha=0.05$ (3.03), applying SAVI is significantly different from TSTS for students who have high critical thinking. Because the mean of $\mathrm{A}_{1} \mathrm{~B}_{1}$ (78.86) is higher than that of $\mathrm{A}_{2} \mathrm{~B}_{1}$ (66.21), it can be concluded that SAVI is more effective than TSTS to teach writing for students having high critical thinking.

d. Because $\mathrm{q}_{\mathrm{o}}$ between cells $\left(\mathrm{A}_{1} \mathrm{~B}_{2^{-}}\right.$ $\mathrm{A}_{2} \mathrm{~B}_{2}$ ) (3.16) is higher than $\mathrm{q}_{\mathrm{t}}$ at the level significance $\alpha=0.05$ (3.03), applying TSTS is significantly different from SAVI for students who have low critical thinking. Because the mean of $A_{1} B_{2}$ (66.64) is lower than that of $\mathrm{A}_{2} \mathrm{~B}_{2}$ (71.93), it can be concluded that TSTS is more effective than SAVI to teach writing for students having low critical thinking.

The following section discusses findings of this research by considering the result of data analysis.

\section{Somatic, Auditory, Visual, Intellectual (SAVI) is more effective than Two Stay Two Stray (TSTS)}

The findings of this research reveal that there is significant difference between teaching writing using SAVI and teaching writing using TSTS. SAVI is more effective than TSTS to teach writing. The mean score of the students who are taught by using SAVI is higher than students who are taught by using TSTS.

SAVI is a method of teaching writing that explores students' imagination, students' ability, and mental cognition in teaching and learning activities, especially in writing. It requires participation of students in discovering knowledge or new concept by giving opportunity to 
students to use all of their senses even physically or intellectually. Besides, SAVI is categorized as an Accelerated Learning (AL), because in this learning style it can use method and media broadly and flexibly. It can be applied by exploring environment of learning and using method that matches with students' preferred learning style in order that the students can learn naturally, quickly, and enjoyably in writing the text. It supported by Meier (2000: 42), learning does not automatically improve by having people stand up and move around, but combining physical movements with intellectual activity and use of all the senses can have a profound effect on learning.

Furthermore, SAVI provides the students opportunities to become active learners. The students enjoy writing well because the components in SAVI give them learning experience which they can use to help them develop their thought into meaningful texts because the learning success comes from what the learners see, say, think, and do in the learning process. This goes in line with Meier (2000: 42) who explains that the component of teaching and learning covers Somatic activity, it is learning by moving and doing; Auditory activity, it is learning by talking and hearing; Visual activity, it learning by observing and picturing; and Intellectual, it is learning by problem solving and reflecting. It means that the components of SAVI (Somatic, Auditory, Visual, Intellectual) provide good atmosphere for students in their writing activity because SAVI is accelerated learning in which it is motivating students' mind, acquiring the information, searching the meaning out, trigerring the memory, exhibiting what the students' know, and reflecting on how the students have learned. Moreover, some activities included in SAVI are able to promote and arise the students' ability in writing. With SAVI method, the students are able to generate their ideas into a good text using a good content, vocabulary, organization, grammar, and mechanic. This principle was done by the teacher in the following four main activities: They are preparation, presentation, practice, and performance. The four main activities used SAVI activities to gain the objective of the lesson which was aimed to the different learning preferences of the students. Somatic which contains of some physical activities are suitable for kinesthetic learners. In preparation, the teacher gave physical exercise, it was used to stimulate the students' motivation to learn. Another activity was deck of question cards. This activity was used to develop the students' ability to choose and write the correct and appropriate words in the sentences. The teacher gave the students deck of question cards, as a review exercise in performance. The activities in auditory such as video, reading aloud and auditory mnemonics or auditory memory device. Auditory mnemonics were given in preparation to help the learners remember the social function, generic structure, and language features of analytical exposition text. While picture, mind map and video example will be good for visual learners to arise the ability of the students to think creatively and develop thoughts in writing the arguments. In presentation, video was used to engage the students' interest. It was used to help students stimulate their knowledge about the topic given. In practice, teacher asked the students to access the information on the web 
as an additional information to help the learners strengthen their ideas in writing. All four aspects in SAVI can be used to raise the students' ability in exploring their thoughts and ideas into a good writing. This method let students to be more imaginative and feel free in creating their own writing.

On the other hand, TSTS is one of the discussion method that begins from the formation group. By discussing and sharing with other groups, the students can assist each other and broaden their knowledge to be used in writing the materials given. Unfortunately, not all the students like working in group. Students who do not get accustomed to working in groups feel uncomfortable since the elements of TSTS which require the students to share the information make them do not work productively and effectively. Each student needs to generate ideas, help each other to organize ideas, and come up with ideas for writing through sharing with other groups. The activity can be one student who is a stronger helps another who is a weaker one that makes the weaker students are not trained to think critically and creatively, even do not show their seriousness in finishing the tasks because this activity such a good opportunity for them to copy their ideas in writing their arguments. As stated by Jacobsen et al. in Fernandez et al. (2001: 31) students tend to do copying one another's work because of one's lack individuality of writings. Moreover, TSTS is one of the discussion method that needs the students to move to the other groups to find the information to be used in writing the materials given. However, not all the students like standing and moving around. For kinesthetic students, these activities are very appropriate but for some students sitting in their chair is better. They felt ashamed to share the information to the other groups because of their lack of self-confidence. Domain in Atmidjaja (2007) says that learning is the greatest game in life and the most fun. It shows that learning should be in the way students like.

\section{The students who have high critical thinking have better writing skil than those who have low critical thinking.}

The findings of this research reveals that students having high critical thinking have better writing skill than those having low critical thinking. The mean score of students having high critical thinking is higher than those having low critical thinking.

The students with high critical thinking have precision and accuracy when they write their own arguments and identify the elements in someone else's argument. They use writing to deepen their understanding of important concepts and to clarify interrelationship between those concepts. They consistently write in such a way as to become clear, precise, accurate, relevant, deep, broad, logical, and significant. In writing the text, they are not afraid to ask questions and they are able to clearly and accurately analyze, evaluate, and assess ideas, statements, and arguments in texts and in their own thinking so that they gain better understanding of the subject matter. It is in line with Ferrett (1997: 13), critical thinkers are able to ask pertinent questions, assess statements and arguments, admit a lack of understanding or information, have a sense of curiosity, are interested in finding new solutions, clearly define a set of criteria for analysing and give feedback, suspend judgment until all 
facts have been gathered and considered, look for evidence to support assumptions and beliefs, adjust opinions when new facts are found, look for proof, examine problems closely, and reject information that is incorrect or irrelevant. Paul and Elder (in Petress, 2004: 2) emphasize that critical thinkers are "asking vital questions, gathering relevant information, testing well-reasoned conclusions and solutions, thinking open minded, recognizing and assessing their assumptions, implications, and practical consequences and communicating effectively". Critical thinkers are clear as to the purpose at hand and the question at issue. They question information, conclusion, and point of view. They strive to be clear, accurate, precise, and relevant. They seek to think beneath the surface, to be logical, and fair (Paul and Elder, 2006: 2).

On the contrary, students with low critical thinking provide irrelevant and confused statements. They lack understanding of important concepts or information and do not state their statements clearly in supporting their established views. They give irrelevant information or fact and offer several solutions without suggesting which is the most appropriate. They are unwilling to pay attention to the others' views or perspectives because they believe with their own opinions. In addition in the classroom, students with low critical thinking tend to be passive. They have a monotonous concept, idea, and perspective in solving the problems. They are unable to come up with their own fresh idea when making a good writing, just produce conventional idea. It is supported by Paul and Elder (in Coughlan, 2007: 7-8) who describe that non-critical thinkers take a simplistic view of the world. They see things in black and white, as either-or, rather than recognizing a variety of possible understanding. They fail to see linkages and complexities. They fail to recognize related elements. Non-critical thinkers take an egotistical view of the world. They take their facts as the only relevant ones. They take their own perspectives as the only sensible ones. They take their goals as the only valid ones. Facione (1998: 9) states that poor critical thinkers are not able to suggest new ideas and alternatives, unable to communicate with others when dealing with complex issues, they lack in the dispositions and cognitive skills, they are disorganized and overly simplistic, spotty about getting the facts, easily distracted, ready to give up at the least hint of difficulty, and intent on a solution that is more detailed than is possible or being satisfied with an overly generalized and uselessly vague response. These are some reasons why students having low critical thinking writing scores are less than those having high critical thinking.

\section{Interaction between teaching methods and students' critical thinking on the students' writing skill}

The findings of the research reveal that there is an interaction between teaching methods and students critical thinking on the students' writing skills. The data shows that SAVI and TSTS have a significant difference to teach writing both for the students who have high critical thinking and low critical thinking.

SAVI is more effective to teach writing to the students having high critical thinking. SAVI makes the 
learners optimize their learning because this method needs the ability to analyze, evaluate, synthesize the information or the data gathered by using a variety of media such as video, picture slide, presentation instrument and web. Paul and Elder in Petress (2004: 2) emphasize that critical thinkers are asking vital questions, gathering relevant information, testing well reasoned conclusions and solutions, thinking open minded, recognizing and assessing their assumptions, implications, and practical consequences and communicating effectively. Moreover, SAVI method can make students become active in writing through the ability for activating background knowledge and describing the material which needs the students who have high critical thinking, because gathering information and activating prior knowledge need their ability to elaborate the information. High critical thinking students like to make somehing while learning process and elaborate the ideas during listening the new information and verbal explanation. It relates to the theory of Moon (2008: 25) that it is clear that critical thinking is something to do with the process of learning — but it is not all learning. It would seem to be a gathering of various processses such as understanding, analysis, synthesis, evaluation and so on and termed 'tools of manipulation of knowledge'. Therefore, SAVI is more effective to teach writing to the students having high critical thinking.

On the other hand, TSTS is more effective to teach writing to the students having low critical thinking. Students having low critical thinking have different characteristics with high critical thinking students. They are categorized by passiveness, no initiation, and tend to follow other ideas. They do task based on what is instructed and do not really want to think beyond. They are less selfconfidence and that they can not give appropriate or relevant arguments to write. The students need the guidance and help during process of writing. According to Lie (2002: 61-62), Two Stay Two Stray is one of the cooperative method that gives chance to the group to share the results and information to other groups. For students having low critical thinking, using TSTS method gives them such an opportunity for them to cheat the results of another group and write them as their ideas. In addition, Students with low critical thinking do not take part in any activities enthusistically. They can not give new ideas and share with others. Moreover, they are not ready to work in challenge situation. As stated by Facione (1998: 9) states that poor critical thinkers are not able to suggest new ideas and alternatives, unable to communicate with others when dealing with complex issues. The activities in TSTS are very effective for them because the students with low critical thinking are helped by others for developing their thoughts in writing some issues related to the materials.

\section{CONCLUSSIONS AND SUGGESTIONS}

There are some research findings that can be taken: (1) SAVI is more effective than TSTS to teach writing; (2) The students with high critical thinking have better writing skill than those having low critical thinking; (3) There is an interaction between teaching methods and students' critical thinking in teaching writing. In this 
case, students having high critical thinking have ,better writing skill than those having low critical thinking when they are taught using SAVI. However, students having low critical thinking have better writing skill when they are taught using TSTS.

Therefore, it is reccomended that: (1) it is better for English teachers to implement SAVI in teaching writing activities, teacher should be creative in choosing media and method to make the students enthusiastic in joining the process of teaching writing; (2) it is better for students to use SAVI, so they can become autonomous learners, do actively use all senses, promote effective team work, create healthier learning environment, and give chance to develop students' thoughts and ideas in writing, and (3) it is better to use the findings of this research as a literature refference for other researches with different variables or different population characteristic.

\section{REFERENCES}

Barkley, F.E., et al. 2005. Collaborative learning technique. San Fransisco: John Willey \& Sons, Inc.

Facione, P. A. 1998. Critical thinking: What it is and why it counts. California: California Academic Press.

Harmer, Jeremy . 1998. How to teach English. Harlow: Pearson Education Limited.

Hinkel, Eli. 2004. Teaching academic ESL writing: Practical techniques in vocabulary and grammar. Mahwah, NJ:
Lawrence Erlbaum Associates, Inc.

Lie, Anita. 2007. Cooperative learning (Mempraktikkan Cooperative Learning di RuangRuang Kelas). Jakarta: Grasindo.

Linse, Caroline T. 2005. Practical English language teaching: Young Learners. In David Nunan (series Ed.). New York: McGraw-Hill Companies, Inc

Meier, Dave. 2000. The accelerated learning handbook: a creative guide to designing and delivering faster, more effective training program. New York: The McGraw-Hill Companies Inc.

Moon, Jennifer. 2008. Critical thinking: an exploration of theory and practice of teaching. New York: Routledge.

Nunan, D. 2003. Methodology in D. Nunan (ed), Practical English Language Teaching. New york: McGraw-Hill Companies.

Paul, R., \& Elder, L. 2009. The miniature guide to critical thinking :concepts and tools. Dillon Beach, Calif : Foundation for Critical Thinking.

Rose, C. \& Nicholl, M.J. 2011. Accelerated learning for the 21st century. Dell, New York.

Scriven, M., and Paul, R. 2009. Defining critical thinking. Foundation for Critical Thinking: Critical Thinking Community Press. 